\title{
Liberalism and American Hegemony: Over and Out
}

\author{
Cooley, Alexander, and Daniel Nexon. Exit from Hegemony: The Unraveling \\ of American Global Order. Oxford University Press, 2020.
}

\section{Jeffrey Mankoff, NDU-INSS, Washington, USA}

Correspondence: jeffrey.a.mankoff.civ@ndu.edu

As Alexander Cooley and Daniel Nexon note in their theoretically grounded and historically informed new book, U.S. international leadership has always been tightly bound up with concern about its impending decline. However, the past two and a half centuries have provided much support for Bismarck's reported observation that God makes special providence for "children, fools, and the United States of America." The challenge for any would-be Cassandra foretelling the decline of the United States or the world it made, therefore, lies in explaining why this time is different. A. Cooley and D. Nexon confront that task head-on in Exit from Hegemony, suggesting that an unprecedented combination of external challengers and internal breakdown have combined to produce a feedback loop hastening the unraveling of an Americandominated world only a generation or so after its post-Cold War apogee.

Part of what makes Exit from Hegemony compelling is that the authors do not merely rehash a series of well-known mistakes but suggest that the nature of what they term the American hegemonic system always contained the seeds of its own demise. Unlike many works in the U.S. declinist tradition, A. Cooley and D. Nexon emphasize the intersection of domestic and foreign challenges, not in isolation from one another, but as an unanticipated product of U.S.-led globalization at the end of the Cold War. In their telling, this cascade of challenges resembles previous eras of hegemonic decline, suggesting that Washington's predicament today echoes the twilight years of British hegemony before World War II more than it does, say, the era of concern about Japan's rise in the 1980s. As the authors show, those factors - and the decline of U.S. hegemony - predated the Trump presidency and continue to operate today.

A. Cooley and D. Nexon's pessimism about the durability of the American hegemonic system places them firmly to one side of an emerging debate on the decline of not just the American hegemonic system but of America itself. More than many other scholars, A. Cooley and D. Nexon accept that the erosion of the American 
hegemonic system is irreversible and that, consequently, "Washington cannot do much to reverse the global shifts in power that motor challenges from above, below, and within." Of course, A. Cooley and D. Nexon are hardly alone in thinking that the end is nigh for the world that Washington created. Their analysis closely tracks that of John J. Mearsheimer, who argued in 2019 that "the liberal international order [is] in deep trouble. The tectonic plates that underpin it are shifting, and little can be done to repair and rescue it."1

As A. Cooley and D. Nexon point out, events have not been kind to scholars predicting the decline of U.S. hegemony in the past. Even though few serious scholars would question the authors' diagnosis of the ills plaguing American hegemony, resistance to the idea that this time is different remains robust. For instance, G. John Ikenberry - long the leading voice in American academia on international order - points to the emphasis on self-improvement inherent in the liberal creed to suggest that the foundations of an international system built on liberalism can endure even if the United States' relative power is diminished. ${ }^{2}$ Similarly, $\mathrm{H}$. Brands notes "that America is simply too powerful, and the international order it has underwritten too robust and successful" for even the Trump presidency to unravel it. ${ }^{3}$

This more optimistic outlook also appears common among the Washington punditocracy. And while the Biden Administration is yet to lay out a comprehensive foreign policy vision, the remarks of leading officials, including the president himself, suggest that they too subscribe to the idea that the American-led order (none, presumably, would call it a hegemonic system) can be salvaged. ${ }^{4}$

A. Cooley and D. Nexon, however, do not share this optimistic outlook. Using simplified historical case studies, they identify three basic pathways that have fatally weakened hegemonic orders in the past - which they term Exit from Above, Exit from Below, and Exit from Within, respectively. And while the U.S. has faced great power rivals, obstreperous allies and clients, and domestic discord in previous eras, the authors suggest that this time is truly different because of the "bootstrapping of challenges to the American order" from all three pathways on a scale that makes it impossible for Washington to continue playing the role to which it has become accustomed. This aggregation of challenges from within and without is not, A. Cooley and D. Nexon suggest, merely an accident of timing but also the result of a contradiction inherent in the nature of the American hegemonic system itself.

\section{Divergence from Convergence}

Much Western academic and policy writing on the topic of international order - and especially the so-called "liberal international order" (which, echoing Voltaire's observation about the Holy Roman Empire, some observers have suggested is not liberal, not international, and not much of an order) - has been fast and loose with definitions. To their credit, A. Cooley and D. Nexon do not fall into the trap

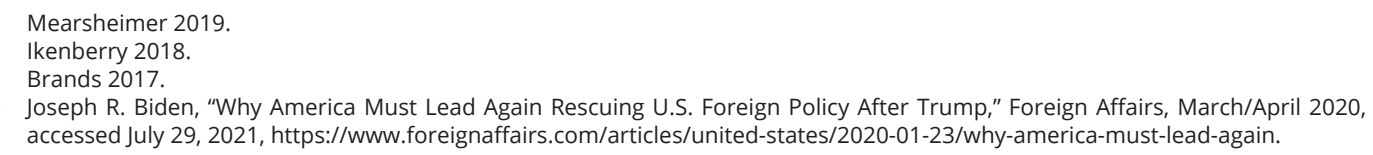


of essentializing or idealizing a liberal international order; indeed, they suggest that "[t] here is no such thing as 'the liberal international order."' Their preference for the term "American hegemonic system" stems from their understanding of order as an evolving set of "rules, norms, and arrangements" or "relatively stable patterns of relationships and practices," whose remit has always been contested. This American hegemonic system is thus only one pillar of a globalized world rather than a universal set of rules and institutions. While they acknowledge that the U.S. has often placed national interest ahead of liberal values and institutions, A. Cooley and D. Nexon recognize that on balance, the American hegemonic system has been more liberal and democratic than whatever is likely to follow in its wake.

Preserving as much of that liberal core as possible requires, according to A. Cooley and D. Nexon, acknowledging that political, economic, and institutional liberalism do not constitute not a package deal. One of the more striking threads running through the book is an attempt to pick apart what the authors term the "convergence wager", i.e. the idea that political, economic, and institutional liberalism is a self-reinforcing package. When liberal reformers at the end of the Cold War pressured leaders of postCommunist and less developed countries to push through political democratization, economic liberalization, and membership in Western-dominated institutions like the International Monetary Fund (IMF), they were operating from a playbook that, they assumed, had been instrumental in the West's victory over Communism. This Western playbook grew out of a perception that the Reagan-era commitment to free markets and democratization had proven its superiority over Soviet-style planning and now offered a universal model for post-Cold War peace and prosperity. This belief not only animated Francis Fukuyama's portrayal of the "end of history" but also underpinned efforts by both Democratic and Republican U.S. administrations to export that model to other states and encode it in the operating system of U.S.-led international institutions.

According to A. Cooley and D. Nexon, the problem was not merely hubris in assuming that the U.S. experience could be universalized, but also a fundamental misunderstanding of how political, economic, and institutional or intergovernmental liberalism could work at cross-purposes. Liberal intergovernmentalism - the creation and expansion of multilateral institutions based on liberal principles - ended up providing insulation for illiberal regimes that find their way inside. The ability of the current Hungarian and Polish governments to take advantage of EU subsidies while undermining EU norms around civil society is one prominent example. Likewise, building on existing work on the rise of kleptocracy and dark money (an issue where A. Cooley has long been a prominent voice), the authors note that the liberalization of financial markets and economic globalization has provided a boon for money laundering and the emergence of a vast empire of offshore jurisdictions (some operated by Western states) that provide a haven for a wide range of illiberal actors, from oligarchs to terrorist groups.

The emergence of Russia and China as illiberal great powers has only deepened the contradiction between these three pillars of the American hegemonic system. Even as they seek to undo elements of the U.S.-led order, Russia and its fellow-travelers are in other ways patrons of the status quo, especially as it regards offshore finance and the mobility of capital. As the U.S. is discovering, Russian investments in infrastructure, 
real estate, and financial institutions in the West complicate efforts to impose sanctions over Russian aggression against its neighbors or illiberal actions at home. The challenge is even more significant with China, a country that holds trillions of dollars of U.S. and European government debt and is deeply integrated into the supply chains of leading Western firms. And though many Western observers and officials now blame China for failing to live up to the commitments it undertook upon joining the World Trade Organization (WTO), another way of looking at the problem is that Beijing is merely using the intergovernmental liberalism of the WTO to shield an increasingly illiberal system. By insisting on the interdependence of all three liberal elements, A. Cooley and D. Nexon suggest that the United States unwittingly left its hegemonic system more vulnerable to the concatenation of challenges it now faces.

\section{Exeunt Omnes?}

Looking around at both the global landscape and the state of American politics, A. Cooley and D. Nexon suggest that the American hegemonic system is not merely ailing, but already on its death bed and that - unlike in previous eras of concern about decline, no deus ex machina like the timely collapse of the Soviet Union will intervene to save it this time. Perhaps the most visible threat to the U.S.-led hegemonic order is the rise of China. Of course, China is not the first great power rival the United States has faced, even since taking up the mantle of hegemony within the "free world" at the end of World War II. Nevertheless, China - especially given its deepening alignment with Russia - represents a much more capable rival than any other the U.S. has faced. China's challenge encompasses not just military power (where, by many measures, the U.S. maintains a sizeable lead), but also as a provider of public, private, and "club" goods such as investment, diplomatic norms (an emphasis on non-interference as an alternative to the promotion of democracy), and multilateral organizations such as the Asian Infrastructure Investment Bank (AIIB) and the Shanghai Cooperation Organization (SCO).

More than many Americans realize, A. Cooley and D. Nexon suggest that China (in tandem on some occasions with Russia) has already eroded key elements of U.S. leadership through building alternative institutions, advancing divergent norms, and military and economic actions that contravene what Washington understands to be the rules of the game. Nor is it only China and Russia: A. Cooley and D. Nexon note that even mid-tier powers like the UAE, Qatar, and even Venezuela have stepped in as goods providers in contravention of U.S. wishes.

Though many analysts downplay the significance of bodies like the SCO as mere "talking shops," A. Cooley and D. Nexon take seriously both their convening role and their ability to incubate and socialize alternative norms. In agreeing to participate in such organizations, A. Cooley and D. Nexon argue, smaller states provide them legitimacy and, in the process, strike a blow at the idea that U.S.-led institutions represent the only foundation for multilateral cooperation.

That is, if China and Russia are challenging the U.S.-led order from above, smaller states eager to diversify their portfolio of international partnerships are also challenging it from below. This attention to the agency of smaller states - what A. Cooley and D. Nexon term the "Exit from Below" pathway out of American hegemony-is a refreshing 
departure from much of the literature on international order that only assigns agency to the great powers, without considering the interests and calculations of other actors in the system. A. Cooley and D. Nexon find that the alacrity with which minor states (including some U.S. allies) sign up for Chinese/Russian-backed organizations or loans is qualitatively different from past eras and represents another indicator that this time is indeed different.

Especially for authoritarian or populist rulers, the lack of conditionality attached to cooperation with Beijing or Moscow represents a positive good, one that helps, as J. Chen Weiss puts it, give birth to a world "safe for autocracy." Indeed, the rise of authoritarian populism both at home and abroad represents the third pathway by which the authors suggest American hegemony is unraveling - what they term Exit from Within. While opposition to the current order exists at multiple points on the political spectrum, A. Cooley and D. Nexon rightly emphasize right-wing populists as the primary internal threat to that order even before the election of D. Trump. They provocatively compare transnational right-wing populism to earlier transnational networks, such as the coalition of Protestant princes and clerics seeking an end to Catholic Habsburg hegemony in $16^{\text {th }}$ century Europe or the international fascist movement of the early $20^{\text {th }}$ century. As with these earlier examples, transnational right-wing populism's efficacy as a counter-order movement is enhanced by its ability to secure support from both great (Russia) and minor (Hungary, Poland) power patrons.

Of course, the Exit from Within pathway also operates within the United States to a greater degree than many acolytes of the American hegemonic system on both the neoconservative right or the liberal internationalist left were prepared to recognizeat least prior to 2016. Amid the rivers of ink spilled so far on the Trump presidency, A. Cooley and D. Nexon do not add much that is new, but they do effectively connect the Trump phenomenon to larger forces working to unravel the American hegemonic system. They identify D. Trump as a player in the kleptocratic shadow world that, they suggest, post-1991 economic liberalization has unwittingly facilitated. D. Trump, in this portrayal, is not only the embodiment of the U.S. white working class' cultural and economic resentments but also as a product of the seamless globalized world he campaigned against. In this sense, the "convergence wager" has turned sour not only because Moscow and Beijing have learned how to exploit its contradictions but also because it has empowered the instruments of its own undoing at home.

\section{No Exit?}

A. Cooley and D. Nexon's dissection of the "convergence wager" and their attention to the nexus between great power rivalry and domestic politics should make Exit from Hegemony a valuable work for both practitioners and scholars. At times though, practitioners and non-specialists may be put off by some of the more abstract discussions. A. Cooley and D. Nexon do not always explain concepts in a way that will make sense to non-specialist readers. Indeed, the authors seem unsure whether they are writing a work to be read in graduate International Relations seminars or aiming 
to influence the public debate and, ultimately, the future direction of American foreign policy. They invoke several terms from academic political science that may or may not be familiar to non-specialists, such as hegemonic stability theory and the tactics of "brokering" and "wedging" that rival powers employ to undermine an alliance relationship. While they make an effort to explain these terms, the authors sometimes assume more patience and familiarity with such concepts on the part of readers than might be warranted for a book aimed at non-specialists.

Particularly frustrating is the attempt to distinguish between what the authors term the "architecture" and the "infrastructure" of international orders. "Architecture," the more familiar of the two terms among policy practitioners, is comprised of "rules and arrangements" structuring the way players in the international system interact. It includes formal institutions like the United Nations and norms like those surrounding the legitimate uses of force.

A. Cooley and D. Nexon use the term "infrastructure," conversely, to mean "the ongoing, often everyday relations, flows, arrangements, and practices that serve as the sinews of international order." In practice, this concept remains quite vague and seems to overlap in some particulars with their concept of architecture. For instance, A. Cooley and D. Nexon list military alliances as a form of infrastructure, alongside trade and financial flows, and even embassies and consulates.

However, NATO, an institutionalized military alliance with a headquarters and a secretariat, also seems to fit their definition of architecture (and is commonly described as part of Europe's security architecture). The lack of clarity about how these two concepts relate to one another complicates the authors' attempt to describe the nature of the international system they are analyzing - a problem that in various forms plagues much of the recent literature on international order. Their overuse of the term "great power" can also be confusing - especially in hybrid forms like "second-tier great power."

Another way in which the book's quest for academic credibility muddles the argument is in the use of graphics. The theoretical chapters in the first half of the book use numerous figures designed to illustrate concepts like the nature of hegemonic orders in general or the operation of America's hegemonic infrastructure. The quality of these visuals tends to be low. They encompass too many elements often fairly abstract - whose relationship to one another the figures themselves do little to clarify. Although designed to help make sense of complex subjects, the visuals seem more likely to put off rather than draw in non-specialist readers.

While aspects of the theoretical discussion can seem unclear, the book's heart lies in the chapters describing the converging pathways accelerating the decline of American hegemony. In taking the role of non-Western, non-liberal international organizations seriously and focusing on the nexus between great power competition and the rise of internal anti-order constituencies in the United States and its allies, A. Cooley and D. Nexon offer a new perspective on the unwinding of American hegemony. The outlook is not encouraging.

With an intelligent mix of historical analogies, references to theoretical concepts introduced earlier, and examples from the contemporary world, A. Cooley and D. Nexon paint a convincing picture of how the idea of a globalized American hegemony is, three decades after its emergence, already becoming an anachronism. This time may 
indeed be different from previous episodes in American history. However, A. Cooley and D. Nexon make a strong case for why the accumulation of challenges facing the American hegemonic system is leading it down the path followed by many onetime hegemons, a unidirectional path leading straight for the exit.

\title{
СПИСОК ЛИТЕРАTУРЫ / REFERENCES
}

Brands, Hal. "The Unexceptional Superpower: American Grand Strategy in the Age of Trump." Survival 59, no. 6 (November 2, 2017): 7-40.

https://doi.org/10.1080/00396338.2017.1399722.

Ikenberry, G. John. "The End of Liberal International Order?" International Affairs 94, no. 1 (January 1, 2018): 7-23. https://doi.org/10.1093/ia/iix241.
Mearsheimer, John J. "Bound to Fail: The Rise and Fall of the Liberal International Order." International Security 43, no. 4 (April 2019): 7-50. https://doi.org/10.1162/isec_a_00342.

\author{
Author \\ Jeffrey Mankoff, \\ Distinguished Research Fellow, National Defense University (NDU), \\ Institute for National Strategic Studies, \\ Washington, DC, 20319-5066. \\ e-mail: jeffrey.a.mankoff.civ@ndu.edu
}

\section{Additional information}

Received: April 28, 2021. Accepted: July 29, 2021.

\section{Disclosure statement}

No protentional conflict of interest was reported by the author. The views expressed in this review are those of the author and are not an official policy or position of the National Defense University,

the Department of Defense or the U.S. Government.

\section{For citation}

Mankoff, Jeffrey. "Liberalism and American Hegemony: Over and Out." Journal of International Analytics 12, no. 3 (2021): 173-179. https://doi.org/10.46272/2587-8476-2021-12-3-173-179

\section{Сведения об авторе}

Джеффри Манкофф,

Заслуженный научный сотрудник, Национальный университет обороны (NDU), Институт национальных стратегических исследований,

Вашингтон, округ Колумбия, 20319-5066.

e-mail: jeffrey.a.mankoff.civ@ndu.edu

\section{Дополнительная информация}

Поступила в редакцию: 28 апреля 2021.

Принята к публикации: 29 июля 2021.

\section{Конфликт интересов}

Автор заявляет об отсутствии потенциального конфликта интересов.

Мнения, выраженные в данной рецензии, принадлежат автору и не являются официальной политикой или позицией Национального университета обороны,

Министерства обороны или правительства США.

\section{Цитирование}

Манкофф, Дж. Конец либерализма и американской гегемонии // Международная аналитика. - 2021. - Том 12 (3). - С. 173-179. 